\title{
Conservation genetics - science in the service of nature
}

\author{
CANSEL TAŞKIN, ${ }^{1}$ JAKUB SKORUPSKI ${ }^{2}$ \\ ${ }^{1}$ Department of Biology, Ankara University, 06930 Ankara, Turkey, ORCID: 0000-0001-6899-701X \\ 2 Institute of Marine and Environmental Sciences, University of Szczecin, Adama Mickiewicza 16 St., 70-383 Szczecin; Polish Society \\ for Conservation Genetics LUTREOLA, Maciejkowa 21 St., 70-374 Szczecin, Poland
}

Corresponding author e-mail: jakub.skorupski@usz.edu.pl

Keywords ecogenomics, extinction risk, extinction vortex, genetic load, genomics, inbreeding depression, management units

Abstract Conservation genetics is a subdicipline of conservation biology which deals with the extinction risk and many other problems of nature conservation by using genetic tools and techniques. Conservation genetics is a very good example of the practical use of scientific achievements in nature protection. Although its name seems to be self-defining, its specific area of interest, conceptual apparatus and methodological workshop are not widely known and recognizable. The purpose of this review is to clarify any ambiguities and inconsistencies in this respect. It explore what is conservation genetics, what research and practical issues does it deal with and how they can be solved.

\section{Genetyka konserwatorska - nauka w służbie przyrody}

Słowa kluczowe depresja wsobna, ekogenomika, genomika, jednostki zarządzania, obciążenie genetyczne, ryzyko wyginięcia, wir wymierania

Streszczenie Genetyka konserwatorska jest subdyscypliną biologii konserwatorskiej, która zajmuje się ryzykiem wyginięcia gatunków i wieloma innymi problemami ochrony przyrody, przy użyciu narzędzi i technik genetycznych. Genetyka konserwatorska jest bardzo dobrym przykładem praktycznego wykorzystania osiągnięć nauki w ochronie przyrody. Choć jej nazwa wydaje się samodefiniująca, to właściwy jej obszar zainteresowań, aparat pojęciowy i warsztat metodyczny nie są powszechnie znane i rozpoznawalne. Celem artykułu przeglądowego jest wyjaśnienie wszelkich niejasności i niespójności w tym zakresie. Artykuł wyjaśnia czym jest genetyka konserwatorska, jakie problemy badawcze i praktyczne podejmuje oraz w jaki sposób mogą być one rozwiązane.

\section{Introduction}

Recognition of the importance of conserving diversity and wildlife populations goes back to Darwin (1896), but the modern field of practice did not really emerge until the latter half of the 20 th century. The birth of conservation genetics is associated with the publication of Frankel's 
(1974) article Genetic Conservation: our evolutionary responsibility and Frankel and Soulè's (1981) book Conservation and evolution.

Conservation genetics is an interdisciplinary science which deals with the genetic factors that affect extinction risk of species and aims to preserve endangered species and biodiversity in general, through genetic methods (Frankham, 2003). This one of the most frequently cited definitions outlines the general area of interest of conservation genetics, but does not include some important details. The following definition shows greater information load and greater precision: conservation genetics is the science of gene pool conservation, to preserve biodiversity and to ensure the continuity of evolutionary and ecological processes responsible for its formation and maintenance (Frankham et al., 2004; Allendorf, Luikart, 2007; Avise, 2008; Skorupski, 2015). Similarly, the definition provided by Frankham, Briscoe and Ballou (2002) - the theory and practice of genetics in the preservation of species as dynamic entities capable of evolving to cope with environmental change to minimize their risk of extinction.

An important consequence of the last two cited definitions is the recognition of the fact that the overriding goal of conservation genetics is to suppress the populations and species gene pools depletion, due to their extinction by non-natural (anthropogenic) causes and restoration of optimal conditions for gene pools natural ability to evolve in order to adapt to environmental changes and minimizing the risk of extinction (Skorupski, 2015). What's more, the conservation genetics strives to stop the decline of biotic diversity driven by destructive human activity, without interfering in natural speciation and processes leading to species disappearance (Skorupski, 2015).

Conservation genetics is a theoretical and applied science within conservation biology, constituting the scientific foundations of nature conservation, and combines and benefits from many disciplines of genetics (molecular, population, evolutionary, ecological, landscape and breeding genetics, as well as genomics) and other biological sciences, such as ecology, systematics, evolutionary biology, bioinformatics and biomathematics (Skorupski, 2015). This combination of different fields of biology makes conservation genetics multidisciplinary science that explore and describe the possibilities of utilizing the theoretical achievements and practical tools of genetics (Soulé, 1985; Frankham et al., 2004; Allendorf, Luikart, 2007; Meine, 2010; Skorupski, 2015).

\section{Scope of conservation genetics interest}

The conservation of nature requires a combination of strategies, including the protection of endangered species, ecological reserves, control of human actions that harm ecosystems, ecosystem restoration, captive breeding, control of non-native species, and conservation biology education (Trombulak et al., 2004).

There are several issues that conservation genetics studies are conducted. Frankham (2003) categorized these main issues into five categories:

- management and reintroduction of captive populations, and the restoration of biological communities,

- description and identification of individuals, genetic population structure, kin relationships, and taxonomic relationships,

- detection and prediction of the effects of habitat loss, fragmentation, and isolation,

- detection and prediction of the effects of hybridization and introgression,

- understanding the relationships between adaptation or fitness and the genetic characters of individuals or populations. 
In genere the conservation genetics focuses on genetic diversity and phylogenetic diversity (Skorupski, 2015). Both terms refer to the gene pool, and are source of other levels of biotic diversity (species and biocenotic diversity), and the resulting diversity at ecosystem, landscape and biogeographical levels (Frankham et al., 2004; Gaston, 2010; Skorupski, 2015). Genetic diversity is the degree of diversity within a species, determined by the differentiation of intraand interpopulation genetic resources, while phylogenetic diversity is understood as a resource of evolutionary history of a species or population (Allendorf, Luikart, 2007; Skorupski, 2015).

According to Skorupski (2015) and Skorupski et al. (2017), and supported by Woodruff (2000), Frankham et al. (2004), Allendorf and Luikart (2007), Avise (2008), the following areas of conservation genetics can be listed:

1. Molecular genetics issues: use of molecular genetic methods in species biological research, identification of molecular markers best describing inter- and intrapopulation genetic variation, application of genetic analysis in counteracting poaching of protected species, determining kinship and genealogy, molecular diagnostics of pathogens associated with invasive alien species, developing non-invasive sampling for genetic analysis.

2. Population genetics issues: inbred depression, outbred depression, preservation of genetic variation of small populations, determination of genetic structure of populations, identification of populations and species at risk of extinction, detection and identification of genetic pollution (GMOs, genetically modified organisms), hybridization and introgression, identification of population size and gender identification, monitoring of invasive alien species populations, accumulation and loss of deleterious mutations, determination of effective population size.

3. Evolutionary genetics issues: explanation of taxonomic uncertainties, definition of management units and units of evolutionary significance within the species, phylogenetic analysis, detection of genetic variation, loss of genetic diversity and evolutionary capacity in response to changes in the natural environment, adaptive genetic variation.

4. Ecological genetics issues: characterization of genomic-environment interactions in transcriptional and epigenetic studies, genotoxicity studies.

5. Landscape genetics issues: genetic isolation and gene flow detection, population fragmentation and gene flow restriction, genetic drift leaving the importance of natural selection.

6. Breeding genetic issues: genetic adaptation to breeding in captivity and its negative effects on the success of reintroduction, enhancement of reproductive potential of individuals keept in captivity, management of captive populations.

7. Genomics issues: cognitive genomic research, multilocus genotyping.

\section{Conservation genetics' methodology}

Methods and techniques used by conservation genetics widely varies due to the broad range of raised issues. Conservation genetics uses a whole range of genetic methods, such as DNA sequencing, real-time PCR, gene editing technologies, analysis of SNPs, microsatellites, mtDNA and nuclear markers, DNA barcoding or reduced representation methods (GBS, RAD-tag, ddRAD sequencing), but also coalescent modelling and Bayesian statistical methods (Skorupski et al., 2017; Moro et al., 2018; Pertoldi, Randi, 2018).

Particular trend is currently the ongoing transition from conservation genetics to conservation genomics (Romanov et al., 2006; Pertoldi et al., 2010; Pertoldi, Randi, 2018). Genomic developments have spawned the assays of micro amounts of DNA in pooled environmental samples, such 
as soil, and environmental DNA (eDNA) methods are becoming integral in a wide range of areas, including conservation, biosecurity and forensics, as well as in monitoring and tracking cryptic species (Thomsen, Willerslev, 2015; Bissett et al., 2016).

Molecular genetic methods are also used widely in forensic evidence for litigation. These include the detection of illegal hunting and collection. To understand these factors, coalescene and gene tree analyses provide useful tools. Also PCR based genetic markers can be used to detect illegal hunting or collecting (Frankham et al., 2004).

\section{Genetics}

Throughout the history scientists had a better understanding of the importance of genetics in conservation. The importance of genetics in conservation biology is first recognized by Darwin (1896). Steadiness of biodiversity depends upon the protection of the environment and maintenance of habitat, but it is the genetics that has played a significant and diverse role in conservation biology in the last few years (Allendorf, Luikart, 2007).

It should be assumed that in the future genetics will play an even more important role in nature conservation than at present. The use of research results on the genome of humans and other organisms will provide not only theoretical knowledge, but also practical solutions that can be implemented in the protection of endangered species. Analyzes of large amounts of data may be of particular importance, the statistical analysis of which, supported by an evolutionary perspective, will allow for a proper assessment of their biological significance and correct inference and forecasting based on these data. In addition, those data will permit an understanding of evolutionary events and processes (nonselective, including bottlenecks or gene flow, or selective, like detrimental or adaptive mutations) that shaped gene pools of endangered species in the past (Trombulak et al., 2004).

Genetic diversity has a major role in conservation. All the phenotypic plasticity is dependent on the genetic variability which helps the individuals to survive and adapt in harsh environments and abiotic stress, thus protect from endangering risk (Soumen, Tanmay, 2016). Genetic diversity is important because it helps to maintain the health of a population, by including alleles that may be valuable in resisting diseases, pests and other environmental stresses. Maintaining diversity gives the population a buffer against change, providing the flexibility to adapt these harsh conditions (Frankham et al., 2004). If the environment changes, a population that has a higher variability of alleles will be better able to evolve and adapt to the new environment. In extreme situations, such as drought or epidemics, diversity could even condition the survival of the population. Thus, if the genetic diversity of a population increases, the risk of extinction decreases (Frankham et al., 2004; Weeks et al., 2016).

The abundant genetic diversity found in large populations contrasts with that found in many small or bottlenecked populations (Garner et al., 2005). Most threatened species have lower genetic diversity than related non-endangered species with large population sizes. Of 170 threatened species examined, $77 \%$ had lower genetic diversity than related non-endangered species. Overall, threatened species have about $60 \%$ of the genetic diversity of non-endangered species. the most likely explanation is that threatened species have suffered reductions in population size that directly result in loss of genetic diversity (Frankham et al., 2004). 


\section{Inbreeding depression and mutation meltdown}

Of the various possible genetic problems which face a declining population, loss of genetic variability and inbreeding depression have historically received most attention (O'Brien, 1994). Inbreeding occurs when related individuals of a species mate with one another. Inbreeding reduces the genetic variability and cause loss of genetic diversity which enables species to be prone to extinction. Inbred individuals generally have reduced fitness in comparison to noninbred individuals from the same population because of their increased homozygosity. Inbreeding depression is the reduction in fitness (or phenotype value) of progeny from matings between related individuals relative to the fitness of progeny between unrelated individuals. Inbreeding depression in natural populations will contribute to the extinction of populations under some circumstances (Keller, Waller, 2002).

The size of a population is important here. It is generally inversely related with inbreeding, the loss of genetic information due to chance events connected with survival and reproduction, and susceptibility to extinction. Therefore, small populations are, in general, at greater risk of extinction than large populations (Trombulak et al., 2004). Nevertheless, assuming that a species has lost useful variability, what are the probable results? One possibility is that fitness will be reduced as a direct consequence of a reduction in the number of heterozygous loci. This proposition stems from the fact that some, and maybe much, selectively important variability is maintained by balanced polymorphisms in which the heterozygote is better than either homozygote. Although such locus-specific effects could operate entirely separately from the more general aspects of inbreeding depression, in practice the two processes are virtually impossible to disentangle (Amos, Balmford, 2001).

For inbreeding depression to affect population viability it must affect traits which influences the population viability. Although inbreeding results in demonstrable costs in captive and wild situations, it has yet to be shown that inbreeding depression has caused any wild population to decline. Similarly, although loss of heterozygosity has baneful impact on individual fitness, no population has gone extinct as a result (Allendorf, Luikart, 2007). According to Amos and Balmford (2001), an alternative solution for the problem of inbreeding depression is based on introduction of new genetic diversity from other populations.

On the other hand, if the genetic load increases in a population, the population might decrease in size, such that destructive mutants of larger effect become efficiently neutral and, subsequently, are more likely to become fixed. This feedback process has been named "mutation meltdown" and, in theory, could result in the extinction of small populations (Lynch et al., 1995; Higgins, Lynch, 2001). However, it is not clear how significant mutation meltdown actually is because the extinction probability owing to other causes might be high in such small populations and other factors could also counter its effects (Hedrick, 2001).

The accumulation of new deleterious mutations is predicted to constitute a significant threat to the survival of finite sexually reproducing populations (Gilligan et al., 1997). Genetic loads, measured as fitness differentials between inbred and non-inbred lines, derive from each population under productivity of single pairs and competitive conditions, while smaller populations are proven to not exhibit greater genetic loads than larger populations under either benign or competitive conditions (Gilligan et al., 1997).

Natural selection is able to remove deleterious alleles from a population, but under natural conditions it takes so long that in the meantime new mutations emerge before the previous ones are removed from the gene pool, especially in the case of recessive alleles. As a result, a specific 
balance is created between the appearance of deleterious alleles by mutation and their removal by selection (mutation-selection equilibrium). Consequently, low frequencies of deleterious alleles (mutation load) occur in all naturally intersecting populations (Gilligan et al., 1997; Frankham et al., 2004).

\section{Extinction vortex}

Inbreeding depression can potentially contribute to a so-called extinction vortex, in which decline reduces fitness which in turn hastens the decline, increasing both inbreeding depression and vulnerability to stochastic events in a destructive feedback loop (Lacy, Lindenmayer, 1995; Amos, Balmford, 2001). The term "extinction vortex" covers the biotic and abiotic forces affecting small populations that draw them into the chain of events leading to progressive decline in size and endanger their long-term survival which make possible the population size downward to extinction (Allendorf, Luikart, 2007).

Fagan and Holmes (2006) compiled a small time-series database of ten vertebrate species (two mammals, five birds, two reptiles and a fish) whose final extinction was witnessed via monitoring. They confirmed that the time to extinction scales to the logarithm of population size. In other words, as populations decline, the time elapsing before extinction occurs becomes rapidly (exponentially) smaller and smaller. They also found greater rates of population decline nearer to the time of extinction than earlier in the population's history, confirming the expectation that genetic deterioration contributes to a general corrosion of individual performance (fitness). Finally, they found that the variability in abundance was also highest as populations approached extinction, irrespective of population size, thus demonstrating indirectly that random environmental fluctuations take over to cause the final extinction regardless of what caused the population to decline in the first place. It was fundamentally the first empirical demonstration that the theory of accelerating extinction proneness occurs as populations decline, meaning that all attempts must be made to ensure large population sizes if there is any chance of maintaining long-term persistence. This relates to the minimum viable population size concept that should underscore each and every recovery and target set or desired for any population in trouble or under conservation scrutiny (Bradshaw, 2008).

\section{Conservation genetics gaps}

Despite the fact that the knowledge about genetic diversity is increased, the insufficiency of applying this information to the conservation has created a gap between genetic knowledge and conservation (Allendorf et al., 2010). Although its recognised importance for species' persistence, integrating genetics into conservation management has proved problematic, creating a so called conservation genetics gap, which could widen with the advent of advanced genomic techniques. Bridging this gap requires a clear understanding of the barriers to use of genetics by conservation practitioners (Taylor et al., 2017).

\section{Management Unit \& Evolutionary Significance Unit}

It is a common belief, that in biological conservation, what should be protected are species (Mace, 2004). As, due to the limited resources, it is not possible to protect all populations 
of a given species, it is necessary to focus on restricted number of local populations, prioritized for conservation purposes in accordance with the concept of the Management Unit (MU), defined as demographically independent populations (Moritz, 1994; Allendorf, Luikart, 2007).

Evolutionarily Significant Unit (ESU), conceptualised by Ryder (1986), is considered as a conservation unit, providing a theoretical background for prioritising taxa for conservation purposes (Moritz, 1994). The ESU may be seen as an entity identical to a species (encompassing one evolutionary lineage), or a species may encompass multiple ESUs. Evolutionarily Significant Units may also constitute a metapopulation or separate populations showing adequate gene flow and sharing a common evolutionary history (Fraser, Bernatchez, 2001). Several, sometimes contrasting, definitions have been proposed for ESU, however all of these definitions refers to "segments of species whose divergence can be measured or evaluated by putting differential emphasis on the role of evolutionary forces at varied temporal scales" (Casacci et al., 2014).

Studies regarding Management Unit (MU) for non-endangered species are much less common. Meanwhile, intraspecific diversity can provide important information on how to identify biogeographic areas and regions for conservation planning. According to Araújo (2002), the study of a large number of different species can help target appropriate areas for conservation purposes by identifying the amount and distribution of species diversity, especially important in case of species distributed in biodiversity hotspots and areas of endemism.

The designation of Management Units and Evolutionarily Significant Units is critical to the planning and achievement of short- and long-term nature conservation and management goals. MUs, as populations that are demographically independent, while maintaining a genetic link with other populations, are subject to short-term nature management objectives, expressed as maintaining stable reproduction of Management Units and excluding excessive pressure on small populations. ESUs have an independent conservation status defined by significant reproductive isolation and unique adaptations, and thus are targeted by the long-term management goals, i.e. preserving the structure, evolutionarily significant differences, maximum genetic diversity and evolutionary potential of native populations (Efremov, 2007).

\section{Genomics}

With the recent developments in genetic tools and technologies, another new research field has emerged - genomics, targeting whole genomes or their great segments. Genomics offer lots of promises, and the ongoing transition from conservation genetics to conservation genomics is currently taking place (Allendorf et al., 2010; Avise, 2010; Ouburg et al., 2010; Funk et al., 2012; Pertoldi, Randi, 2018).

The growing importance of genomics in conservation biology concerns especially identifying the segments of genomes responsible for local adaptation and therefore important for preservation, but also ecological issues, such as population size estimation using non-invasive methods (Puechmaille, Petit, 2007). Genomic methods can therefore be an alternative to costly and laborious radio and satellite tracking tracking in estimating movements and dispersal (Fabbri et al., 2007; Sahlsten et al., 2008).

One area where genomic data is particularly helpful is in attempts to trace past demographic processes, such as population size fluctuations, where traditional genetic techniques, using a limited number of markers, are insufficient. Meanwhile, genomic data, even from a single individual, can provide useful insights in an endangered species past population dynamics (Zhan et al., 2013). Genomic analysis of the past demographics can explain whether given species have 
been endangered and bottlenecked also during its past evolutionary history or whether its present threat status is a consequence of current events and situation of the species (McMahon et al., 2014). The knowledge about the past demographics could be used in planning and implementation of conservation actions (McMahon et al., 2014).

The techniques, approaches and data of functional genomics are currently often adopted and applied to native populations, since gene function can only be defined in close relation to the environment in which it is measured (Feder, Mitchell-Olds, 2003; Ouborg, Vriezen, 2007). The problem is the transposition of the functional genetics achievements for model organisms (Arabidopsis thaliana, Caenorhabditis elegans, Mus musculus and Drosophila melanogaster), in a limited set of well-defined genotypes and under strictly controlled environmental conditions, into real natural conditions and situations. There are several challenges to developing an ecological and evolutionary approach to genomics. These involve changing from genomic model species, that have enough genomic resources and tools available, to ecological model species, for which these resources and tools are generally absent. Adopting an ecological and evolutionary functional genomic approach for conservation purposes referees to as ecogenomics, often utilizing techniques and approaches originally designed for detailed studies at the individual level for the population-wide studies (Feder, Mitchell-Olds, 2003).

\section{Conclusions}

To sum up, conservation genetics, as a subdicipline of conservation biology, plays an important role in conservation of biodiversity. Using genetic tools and implementing genomics into conservation enables better understanding of how to preserve the natural environment. The importance and application of this interdiciplinary science is increasing day by day.

The role of conservation genetics is to provide a scientific basis for nature conservation activities, and conservator geneticists role is to transfer knowledge and skills, i.e. scientific research results into practice, to carry out appropriate scientifically validated conservation practices (Skorupski, 2015; Skorupski et al., 2017).

Conservation genetics should focus not only on endangered and extinct species, but efforts taken should strive to protect the biotic diversity (gene pools), including anticipatory and preventive actions that protect species or populations from extinction threat (Skorupski, 2015).

\section{References}

Allendorf, F.W., Hohenlohe, P.A., Luikart, G. (2010). Genomics and the future of conservation genetics. Nature Reviews Genetics, 11, 697-709.

Allendorf, F.W., Luikart, G. (2007). Conservation and the Genetics of Population. London: Blackwell Publishing.

Amos, W., Balmford, A. (2001). When does conservation genetics matter? Heredity, 87, 257-265.

Araújo, M.B. (2002). Biodiversity hotspots and zones of ecological transition. Conserv. Biol., 16 (6), 1662 1663.

Avise, J.C. (2008). The history, purview, and future of conservation genetics. In: S.P. Carroll, C.W. Fox (eds.), Conservation biology: evolution in action (pp. 5-15). Oxford: Oxford University Press.

Avise, J.C. (2010). Perspective: Conservation enters the genomic era. Conservation Genetics, 11, 665-669. 
Bissett, A. et al. (2016). Introducing BASE: the biomes of Australian soil environments soil microbial diversity database. GigaScience, 5, 1-11.

Casacci, L.P., Barbero, F., Balletto, E. (2014). The "Evolutionarily Significant Unit" concept and its applicability in biological conservation. Italian Journal of Zoology, 81 (2), 182-193.

Caughley, G. (1994). Directions in conservation biology. Journal of Animal Ecology, 63, 215-244.

Darwin, C. (1896). The Variation of Animals and Plants under Domestication. Vol. II. New York: D. Appleton \& Co.

Efremov, V.V. (2007). Population as a conservation and management unit in vertebrate animals. Zh Obshch Biol., 68 (3), 205-220.

Fabbri, E., Miquel, C., Lucchini, V., Santini, A., Caniglia, R., Duchamp, C., Weber, J.-M., Lequette, B., Marucco, F., Boitani, L., Fumagalli, L., Taberlet, P., Randi, E. (2007). From the Apennines to the Alps: colonization genetics of the naturally expanding Italian wolf (Canis lupus) population. Molecular Ecology, 16, 1661-1671.

Fagan, W.F., Holmes, E.E. (2006). Quantifying the extinction vortex. Ecology Letters, 9, 51-60.

Feder, M.E., Mitchell-Olds, T.M. (2003). Evolutionary and ecological functional genomics. Nat. Rev. Genet., 4, 651-657.

Frankel, O.H., Soulé, M.E. (1981). Conservation and evolution. Cambridge: Cambridge University Press.

Frankel, O.H. (1974). Genetic conservation: Our evolutionary responsibility. Genetics, 78, 53-65.

Frankham, R., Ballou, J.D., Briscoe, D.A., McInnes, K.H. (2004). A Primer of Conservation Genetics. Cambridge: Cambridge University Press.

Frankham, R., Ballou, J.D., Briscoe, D.A. (2004). Introduction to Conservation Genetics. Cambridge: Cambridge University Press.

Frankham, R. (2003). Genetics and conservation biology. Comptes Rendus Biologies, 326, 22-29.

Fraser, D.J., Bernatchez, L. (2001). Adaptive evolutionary conservation: Towards a unified concept for defining conservation units. Molecular Ecology, 10, 2741-2752.

Funk, W.C., McKay, J.C., Hohenlohe, P.A., Allendorf, F.W. (2012). Harnessing genomics for delineating conservation units. Trends in Ecology \& Evolution, 27, 489-495.

Garner, A., Rachlow, J.L., Hicks, J.F. (2005). Patterns of Genetic Diversity and Its Loss in Mammalian Populations. Conservation Biology, 19, 1215-1221.

Gaston, K.J. (2010). Biodiversity. In: N.S. Sodhi, P.R. Ehrlich (eds.), Conservation Biology for All (pp. 27-44). Oxford: Oxford University Press.

Gilligan, D.M., Woodworth, L.M., Montgomery, M.E., Briscoe, D.A., Frankham, R. (1997). Is Mutation Accumulation a Threat to the Survival of Endangered Populations? Conservation Biology, 11 (5), 1235-1241.

Hedrick, P., Miller, P. (1992). Conservation Genetics: Techniques and Fundamentals. Ecological Applications, 2 (1), 30-46.

Higgins, K., Lynch, M. (2001). Metapopulation extinction caused by mutation accumulation. Proc. Nat. Acad. Sci. U. S. A., 98, 2928-2933.

Keller, L.F, Waller, D.M. (2002). Inbreeding effects in wild populations. Trends in Ecology \& Evolution, 17, 230-241.

Lacy, R.C., Lindenmayer, D.B. (1995). A simulation study of the impacts of population subdivision on the mountain bushtail possum Trichosurus caninus Ogilby (Phalangeridae, Marsupialia) in south-eastern Australia. 2. Loss of genetic variability within and between subpopulations. Biol. Cons., 73, 131-142.

Lynch, M., Conery, J., Bürger, R. (1995). Mutation meltdowns in sexual populations. Evolution, 49 (6), 1067-1080. 
Mace, G.M. (2004). The role of taxonomy in species conservation. Philosophical Transaction of the Royal Society of London B, 359, 711-719.

McMahon, B.J., Teeling, E.C., Höglund, J. (2014). How and why should we implement genomics into conservation? Evolutionary Applications, 7, 999-1007.

Meine, C. (2010). Conservation biology: past and present. In: N.S. Sodhi, P.R. Ehrlich (eds.), Conservation Biology for All (pp. 7-26). Oxford: Oxford University Press.

Moritz, C. (1994). Defining ‘Evolutionarily Significant Units' for conservation. Trends in Ecology \& Evolution, 9, 373-375.

Moro, D., Byrne, M., Kennedy, M., Campbell, S., Tizard, M. (2018). Identifying knowledge gaps for gene drive research to control invasive animal species: the next CRISPR step. Global Ecology and Conservation, 13, $\mathrm{e} 00363$.

O’Brien, S.J. (1994). A role for molecular genetics in biological conservation. Proc. Natl. Acad. Sci. U.S.A., 91, 5748-5755.

Ouborg, N.J., Pertoldi, C., Loeschcke, V., Bijlsma, R., Hedrick, P.W. (2010). Conservation genetics in transition to conservation genomics. Trends in Genetics, 26 (4), 177-187.

Ouborg, N.J., Vriezen, W.H. (2007). An ecologist's guide to ecogenomics. J. Ecol., 95, 8-16.

Pertoldi, C., Randi, E. (2018). The ongoing transition at an exponential speed from Conservation genetics to Conservation genomics. Gen. Biodiv. J, 2 (2), 47-54.

Pertoldi, C., Wójcik, J., Tokarska, M., Kawałko, A., Kristensen, T., Loeschcke, V., Gregersen, V., Coltman, D., Wilson, G., Randi, E., Henryon, M., Bendixen, C. (2010). Genome variability in European and American bison detected using the BovineSNP50 BeadChip. Conserv. Genet., 11, 627-634.

Puechmaille, S., Petit, E.J. (2007). Empirical evaluation of non-invasive capture-mark-recapture estimation of population size based on a single sampling session. Journal of Applied Ecology, 44, 843-852.

Romanov, M.N., Koriabine, M., Nefedov, M., de Jong, P.J., Ryder, O.A. (2006). Construction of a Californian condor BAC library and first-generation chicken-condor comparative physical map as an endangered species genomics resource. Genomics, 88, 711-718.

Ryder, O.A. (1986). Species conservation and systematics: The dilemma of the subspecies. Trends in Ecology \& Evolution, 1, 9-10.

Sahlsten, J., Thörngren, H., Höglund, J. (2008). Inference of hazel grouse population structure using multilocus data: a landscape genetic approach. Heredity, 101, 475-482.

Skorupski, J., Panicz, R., Śmietana, P., Napora-Rutkowski, Ł., Soroka, M., Kolek, L., Budniak, M., Wąsowicz, B., Keszka, S., Kempf, M., Moska, M., Zatoń-Dobrowolska, M. (2017). Conservation genetics in Poland - theory and practice. Szczecin: Polish Society for Conservation Genetics LUTREOLA $\&$ Faculty of Biology, University of Szczecin.

Skorupski, J. (2015). Deklaracja Ideowo-Programowa Polskiego Towarzystwa Genetyki Konserwatorskiej LUTREOLA. Szczecin: Polish Society for Conservation Genetics LUTREOLA.

Soulé, M.E. (1985). What Is Conservation Biology? BioScience, 35 (11), 727-734.

Taylor, H.R., Dussexa, N., van Heezik, Y. (2017). Bridging the Conservation Genetics Gap by Identifying Barriers to Implementation for Conservation Practitioners. Global Ecology and Conservation, 10, 231-242.

Thomsen, P.F., Willerslev, E. (2015). Environmental DNA: an emerging tool in conservation for monitoring past and present biodiversity. Biological Conservation, 183, 4-18.

Trombulak, S., Omland, K., Robinson, J., Lusk, J., Fleischner, T., Brown, G., Domroese, M. (2004). Principles of Conservation Biology: Recommended Guidelines for Conservation Literacy from the Education Committee of the Society for Conservation Biology. Conservation Biology, 18, 1180-1190. 
Weeks, A., Stoklosa, J., Hoffmann, A. (2016). Conservation of genetic uniqueness of populations may increase extinction likelihood of endangered species: the case of Australian mammals. Frontiers in Zoology, 13, 31 .

Woodruff, D.S. (2000). Populations, species and conservation genetics. In: S. Levin (ed.), Encyclopedia of Biodiversity. Vol. 4 (pp. 811-829). San Diego: Academic Press.

Zhan, X. et al. (2013). Peregrine and saker falcon genome sequences provide insights into evolution of a predatory lifestyle. Nature Genetics, 45, 563-568.

Cite as: Taşkın, C., Skorupski, J. (2020). Conservation genetics - science in the service of nature. Acta Biologica, 27, 131-141. DOI: 10.18276/ab.2020.27-12. 